\title{
Efficient Resource Recovery Options from Municipal Solid Waste: Case Study of Patna, India
}

\author{
HERAMBPRASAD DIGAMBAR GANDHE ${ }^{1}$ and AWKASH KUMAR ${ }^{2 *}$
}

\author{
${ }^{1}$ Department of Technology, Savitribai Phule Pune University, Pune, Maharashtra - 411007, India. \\ ${ }^{2}$ Centre for Environmental Science and Engineering, Indian institute of Technology Bombay, \\ Mumbai - 400 076, India.
}

http://dx.doi.org/10.12944/CWE.11.1.09

(Received: March 15, 2016; Accepted: April 04, 2016)

\begin{abstract}
Solid waste management is one of the biggest issues in India as well as in the world. The generation of solid waste should be estimated for proper management of municipal solid waste (MSW) of the cities. The segregation, collection, transportation and disposal of MSW are currently done in very unscientific and causal way in India and in many other developing countries. This creates problem for environment in terms of water, air and odour pollution. In this study, the characteristics of MSW have been estimated for Patna city and management has been carried out for recovery of resources. The components of MSW have been estimated and based on that, moisture, density and energy content have been quantified. Afterwards, chemical compositions have been calculated and chemical formula has been made for MSW. This composition can help to estimate requirement of oxygen to degrade MSW and recovery of methane and carbon dioxide from MSW. Generally, landfill for solid waste management is planned for fifteen years or more than that. It is carried out in several parts or layers which take many years. In this paper, the calculation of energy content, requirement of oxygen to degrade MSW and recovery of methane, carbon dioxide from MSW have been carried out for a year which can be done for whole landfill period.
\end{abstract}

Keywords: Physical Characteristics, Energy Contain, Chemical Characteristics.

\section{INTRODUCTION}

Uncontrolled growth of the urban population in developing countries in recent years has made solid waste management an important issue ${ }^{1}$. The rate of urbanization has improved quality of life but at same time it has adverse effect on environment. Urbanization is increasing the level of air, noise, water pollution and solid waste generation their complexities ${ }^{2}$. Few decades ago, environment was not of any concern of scientific efforts for developing countries like India and even solid waste management was not prime concern in developing countries. The quantity of municipal solid waste (MSW) has increased tremendously with improved life style and social status of the populations in urban centers ${ }^{3}$. Waste management and disposal is a big issue that India is facing today, since about $90 \%$ of waste is currently disposed of by open dumping ${ }^{4}$. The generation of solid waste causes air, water and odour pollution. The municipal solid waste management is not well structured at many places in India ${ }^{5}$. Municipal corporations in developing countries are not able to handle increasing quantities of waste, which results in uncollected waste on roads and in other public places ${ }^{6}$. Solid waste management is one among essential services provided by municipal authorities in the country to keep urban centers clean. It has been noticed that $90 \%$ is dumped in open area which creates problem to public health and the 
environment ${ }^{7}$. The mixed municipal solid waste are dumped at the site and left to self-degradation and management ${ }^{8}$. Looking at the situation of MSW, some non-governmental organizations initiated working in the direction to highlight the pathetic situation of MSW of Indian cities. The activities of the public and various organizations resulted in the importance of MSW aspects of environmental management. MSW is an essential by-product of everyday living ${ }^{9}$. The proper segregation at the site, collection from the site, transportation and disposal to landfills site could be effective to manage MSW ${ }^{10}$. Geographical Information System (GIS) based approach is used for selecting optimum routing option for transportation of MSW ${ }^{1}$. The important role also can be seen of Zero waste technology using reuse and recycling the waste.

The study is carried for solid waste management in Patna city. It generates 511 Ton/day solid waste where $51.96 \%$ compostable, $12.57 \%$ recyclable, $36 \%$ moisture and $0.37 \mathrm{~kg} / \mathrm{c} /$ day waste generation rate with $18.62 \mathrm{C} / \mathrm{N}$ ratios ${ }^{11}$. MSW in Patna is disposed of in an unscientific manner without considering environmental impacts ${ }^{2}$. The amount of recovered methane gas is estimated here.

\section{Study Area}

Patna city is situated at Southern Bank of Ganga with ' $\mathrm{B}$ ' category of town. The city is approximately $35 \mathrm{~km}$ long and $16 \mathrm{~km}$ wide and divided into seventy two wards. This is the capital of Bihar state of India whose population is 13.7 lakh as per 2001 Census and area is $107 \mathrm{~km}^{2}$. Studies are done for the solid waste problem in six areas of Patna with reference to the total generation of solid waste/day/household, quality of the solid waste, awareness level and performance of Patna Municipal Corporation (PMC).

\section{Methodology}

A review for municipal solid waste management of India reported physical characteristics of municipal solid waste for many metrocities ${ }^{12}$. So, the physical characteristics of solid waste for Patna city were taken from a study ${ }^{12}$. The typical percentage of moisture content, density and energy content for each component were used to calculate the same for MSW in this study ${ }^{13}$. Chemical composition was estimated for MSW using typical values of MSW component ${ }^{14}$. Chemical characterization was done for carbon, hydrogen, oxygen, nitrogen and sulfur for each component of MSW then the same was calculated for MSW. Afterwards, mass was calculated for chemical composition and chemical formulation was made using molar weight.

\section{RESULTS AND DISCUSSION}

Moisture content (\%), dry mass $(\mathrm{kg})$, volume and total energy for MSW have been calculated in Table 1. The overall moisture content and density for MSW is $35.43 \%$ and $204 \mathrm{~kg} / \mathrm{m}^{3}$. The energy content as discarded solid waste is $8.4 \mathrm{MJ} / \mathrm{kg}$ while energy content for dry ash and ash free dry ash are 13 and $14.1 \mathrm{MJ} / \mathrm{kg}$ respectively. Here, $5 \%$ ash content was assumed.

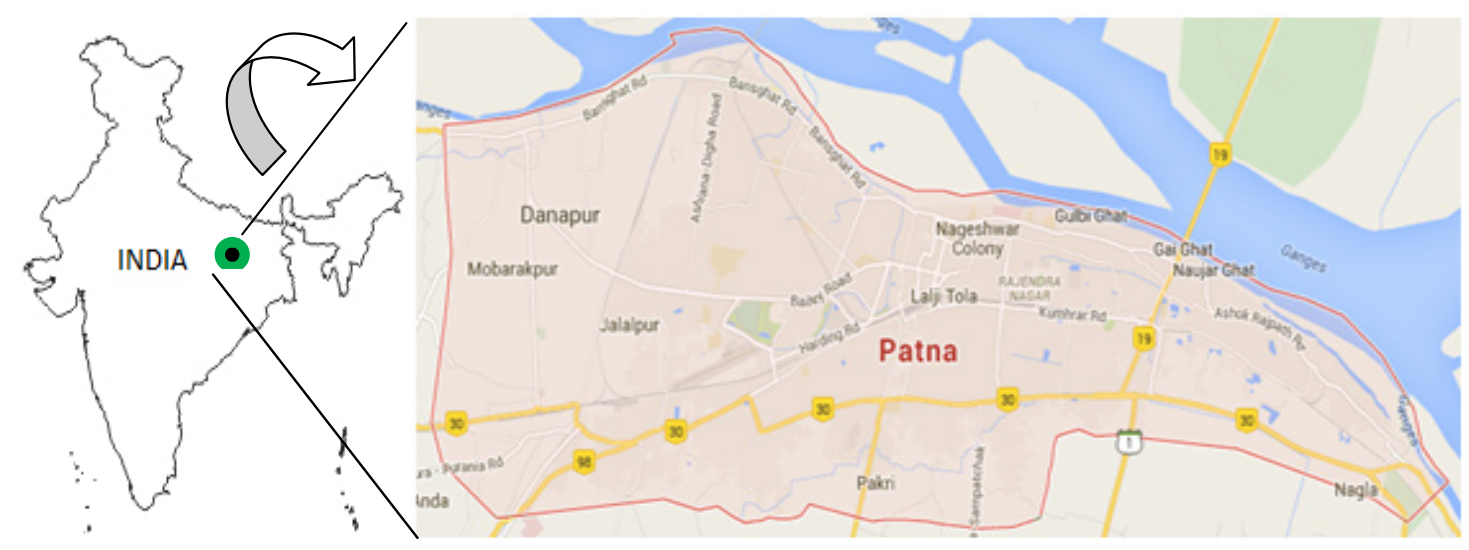

Fig. 1: Study area "Patna" 


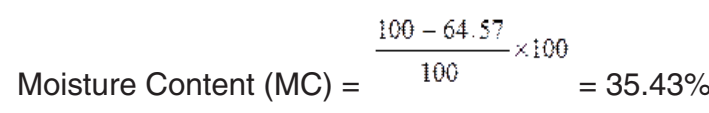

Density $=\left|\frac{\text { maxs }}{\text { Equ wolmet }}=\frac{100}{0.49}\right|=204 \mathrm{~kg} / \mathrm{m}^{3}$

Energy Content $=\frac{\text { total energy }}{\text { tatal mass }}=\frac{840}{100}=8.4 \mathrm{MJ} / \mathrm{kg}$ as discarded

Energy Content (dry ash) $=\left|E \times \frac{100}{100-\% M C}\right|$

$=8.4 \times \frac{100}{100-64.57}=13 \mathrm{MJ} / \mathrm{kg}$

Energy Content (Ash free dry ash) $=$

$$
E \times \frac{100}{100-\% A C-\% A s h}
$$

$$
=8.4 \times \frac{100}{100-5-64.57}=14.1 \mathrm{MJ} / \mathrm{kg}
$$

The total MSW generation in Patna city is 511 tons/day and the total dry mass of MSW is 330 tons/day. The total energy content (Dry Ash) is $4.3 \times 10^{6} \mathrm{MJ} /$ day while energy content (Ash free Dry Ash) is $4.4 \times 10^{6} \mathrm{MJ} /$ day. The chemical composition of MSW has been shown in Table 2 and Table 3.

The oxygen requirement for MWS is $1.9 \times 10^{5} \mathrm{~kg} \mathrm{O} /$ day or $1.33 \times 10^{8} \mathrm{~L}$ of $\mathrm{O}_{2}$ /day to degrade MSW. The present MSW of Patna city

\begin{tabular}{|c|c|c|c|c|c|c|c|}
\hline $\begin{array}{l}\text { Name of } \\
\text { Component }\end{array}$ & $\begin{array}{c}\% \text { of } \\
\text { Composition }\end{array}$ & $\begin{array}{c}\text { Moisture } \\
\text { Content \% }\end{array}$ & $\begin{array}{c}\text { Dry Mass } \\
\text { (kg) }\end{array}$ & $\begin{array}{r}\text { Density } \\
\left(\mathrm{kg} / \mathrm{m}^{3}\right)\end{array}$ & $\begin{array}{l}\text { Volume } \\
\qquad\left(\mathrm{m}^{3}\right)\end{array}$ & $\begin{array}{l}\text { Energy } \\
\text { (MJ/kg) }\end{array}$ & $\begin{array}{c}\text { Total Energy } \\
\text { (MJ) }\end{array}$ \\
\hline Paper & 4 & 6 & 3.76 & 85 & 0.047 & 16.75 & 67 \\
\hline Textile & 5 & 10 & 4.5 & 65 & 0.078 & $17 . .45$ & 87.25 \\
\hline Leather & 2 & 10 & 9.8 & 160 & 0.031 & 17.45 & 34.9 \\
\hline Plastic & 6 & 2 & 5.88 & 65 & 0.092 & 32.60 & 195.6 \\
\hline Metal & 1 & 3 & 0.97 & 320 & 0.003 & 0.70 & 0.7 \\
\hline Glass & 2 & 2 & 1.96 & 198 & 0.010 & 0.15 & 0.3 \\
\hline Ash, fine other & 35 & 8 & 32.2 & 480 & 0.073 & 7 & 245 \\
\hline Compostable & 45 & 70 & 13.5 & 290 & 0.155 & 4.65 & 209.25 \\
\hline Total & 100 & & 64.57 & & 0.49 & & 840 \\
\hline
\end{tabular}

Table 1: Physical characteristics of solid waste for Patna city (By weight)

Table 2: Chemical Characteristics of Solid Waste

\begin{tabular}{lcccccccc}
\hline Component & $\begin{array}{c}\text { Wet mass } \\
(\mathbf{K g})\end{array}$ & $\begin{array}{c}\text { Dry mass } \\
\mathbf{( k g )}\end{array}$ & $\mathbf{C}$ & $\mathbf{H}$ & $\mathbf{O}$ & $\mathbf{N}$ & $\mathbf{S}$ & Ash \\
\hline Paper & 4 & 3.76 & 1.64 & 0.864 & 5.076 & 0.351 & 0.054 & 0.675 \\
Textile & 5 & 4.5 & 2.475 & 0.23 & 1.65 & 0.0112 & 0.007 & 0.23 \\
Leather & 2 & 9.8 & 1.08 & 0.03 & 1.404 & 0.207 & 0.007 & 0.112 \\
Plastic & 6 & 5.88 & 3.53 & 0.144 & 0.208 & 0.18 & 0.007 & 0.18 \\
Metal & 1 & 0.97 & - & 0.42 & 1.34 & - & - & 0.59 \\
Glass & 2 & 1.96 & - & - & - & - & - & - \\
Ash, fine other & 35 & 32.2 & 8.47 & - & - & - & - & - \\
Compostable & 45 & 13.5 & 6.48 & 0.97 & 0.64 & 0.161 & 0.06 & 21.896 \\
Total & 100 & 64.57 & 23.68 & 2.76 & 10.32 & 0.910 & 0.13 & 23.68 \\
\hline
\end{tabular}


Table 3: Ultimate Analysis of Combustible Components

\begin{tabular}{lccccc}
\hline Component & Mass $(\mathbf{k g})$ & Kg/mole & Mole & Ratio w.r.t. S & Ratio w.r.t. N \\
\hline C & 23.68 & 12 & 1.97 & 492.5 & 28.14 \\
H & 2.67 & 1 & 2.67 & 667.5 & 38.14 \\
O & 10.32 & 16 & 0.645 & 161.25 & 9.14 \\
N & 0.91 & 14 & 0.07 & 17.5 & 1 \\
S & 0.41 & 32 & 0.004 & 1 & \\
\hline
\end{tabular}

can generate methane gas $\left(\mathrm{CH}_{4}\right) 2.46 \times 10^{5} \mathrm{~kg} /$ day $3.44 \times 10^{8} \mathrm{~L} /$ day and carbon dioxide $\left(\mathrm{CO}_{2}\right) 5 \times 10^{5} \mathrm{~kg} /$ day or $2.55 \times 10^{8} \mathrm{~L} /$ day. The recovery from solid waste can be utilized to proper landfilling of MSW.

$\mathrm{C}_{492.5} \mathrm{H}_{667.5} \mathrm{O}_{161.25} \mathrm{~N}_{17.5} \mathrm{~S}$

$\mathrm{C}_{28.14} \mathrm{H}_{38.14} \mathrm{O}_{9.14} \mathrm{~N}_{17.5}$

Molecular weight $=536.06 \mathrm{~kg}$

\section{Oxygen required for complete aerobic} stabilization

$\mathrm{C}_{3} \mathrm{H}_{b} \mathrm{O}_{c} \mathrm{~N}_{d}+\frac{4 a+b-2 c-3 d}{4} \mathrm{O}_{2} \rightarrow \mathrm{aCO}_{2}+\frac{b-3 d}{2} \mathrm{H}_{2} \mathrm{O}+\mathrm{dNH}_{3}$

$a=28.14, b=38.14, c=9.14, d=1$

$\frac{4 a+b-2 c-3 d}{4}=32.35$

Since $536.06 \mathrm{~kg}$ solid waste requires $32.35 \times 32 \mathrm{~kg} \mathrm{O}_{2}$

So $5.1 \times 10^{5} \mathrm{~kg}$ solid waste requires

$\frac{32.35 \times 32}{536.06} \times 5.1 \times 10^{5} \mathrm{~kg} \mathrm{O}_{2}=1.9 \times 10^{5} \mathrm{~kg} \mathrm{O}_{2} /$ day At S.T.P.

$32 \mathrm{~kg} \mathrm{O}_{2}=22.4 \times 10^{3}$ lit of $\mathrm{O}_{2}$

$1.9 \times 10^{5} \mathrm{~kg} \mathrm{O}_{2}=\frac{22.4 \times 10^{3}}{32} \times 1.9 \times 10^{5}$

$L=1.33 \times 10^{8} \mathrm{~L}$ of $\mathrm{O}_{2} /$ day

\section{Recovery of Methane gas}

$\mathrm{C}_{2} \mathrm{H}_{6} \mathrm{O}_{c} \mathrm{~N}_{d}+\frac{4 a-b-2 c+3 d}{4} \mathrm{O}_{2} \rightarrow \frac{4 a+b-2 c-3 d}{8} \mathrm{CH}_{4}+\frac{4 a-b+2 c+3 d}{4} \mathrm{CO}_{2}+\mathrm{dNH}_{3}$

$\frac{4 a+b-2 c-3 d}{8}=16.175$
Since $536.06 \mathrm{~kg}$ solid waste produced $16.175 \times 16$ $\mathrm{kg} \mathrm{CH}_{4}$

So $5.1 \times 10^{5} \mathrm{~kg}$ solid waste required

$$
\frac{16.175 \times 16}{536.06} \times 5.1 \times 10^{5} \mathrm{~kg} \mathrm{CH}_{4}
$$

$=2.46 \times 10^{5} \mathrm{~kg} \mathrm{CH}_{4} /$ day

At S.T.P.

$16 \mathrm{~kg} \mathrm{CH}_{4}=22.4 \times 10^{3}$ lit of $\mathrm{CH}_{4}$

$2.46 \times 10^{5} \mathrm{~kg} \mathrm{CH}_{4}=\mathrm{L}=3.44 \times 10^{8} \mathrm{~L}$ of $\mathrm{CH}_{4} /$ day

\section{Recovery of Carbon dioxide gas}

$\frac{4 a-b+2 c+3 d}{4}=11.96$

Since $536.06 \mathrm{~kg}$ solid waste produced $11.96 \times 44$ $\mathrm{kg} \mathrm{CO}_{2}$

So $5.1 \times 10^{5} \mathrm{~kg}$ solid waste required

$$
\frac{11.96 \times 44}{536.06} \times 5.1 \times 10^{5} \mathrm{~kg} \mathrm{CO}
$$

$=5 \times 10^{5} \mathrm{~kg} \mathrm{CO} /$ day

At S.T.P.

$44 \mathrm{~kg} \mathrm{CO}=22.4 \times 10^{3}$ lit of $\mathrm{CO}_{2}$

$5 \times 10^{5} \mathrm{~kg} \mathrm{CO}_{2}=\frac{22.4 \times 10^{3}}{44} \times 5 \times 10^{5}$

$\mathrm{L}=2.55 \times 10^{8} \mathrm{~L}$ of $\mathrm{CO}_{2} /$ day

\section{CONCLUSIONS}

In India and many other developing countries, the segregation, collection, transportation and disposal of municipal solid waste (MSW) are generally done in a very unscientific way presently. This leads problems for environment in terms of water, air and odour pollution. This paper presented 
a study for solid waste management for an urban city Patna of India. The components of MSW have been estimated and based on that, $35.43 \%$ moisture, $204 \mathrm{~kg} / \mathrm{m}^{3}$ density and $14.1 \mathrm{MJ} / \mathrm{kg}$ (dry ash) energy content have been quantified. Afterwards, chemical compositions have been calculated and chemical formula has been made as $\mathrm{C}_{28.14} \mathrm{H}_{38.14} \mathrm{O}_{9.14} \mathrm{~N}_{17.5}$ for MSW. This composition can help to estimate $1.33 \times 10^{8} \mathrm{~L}$ of $\mathrm{O}_{2}$ /day requirement of oxygen to degrade MSW and recovery of $3.44 \times 10^{8} \mathrm{~L}$ of methane/day and $2.55 \times 10^{8} \mathrm{~L}$ of carbon dioxide/day from MSW.
Generally, landfill for solid waste management is planned for fifteen years or more than that. It is carried out in several parts or layers which take many years. The calculation of energy content, requirement of oxygen to degrade MSW and recovery of methane, carbon dioxide from MSW have been carried out for a year which can be extended for whole landfill period.

\section{REFERENCES}

1. M. K. Ghose, a K. Dikshit, and S. K. Sharma, "A GIS based transportation model for solid waste disposal-a case study on Asansol municipality," Waste Manag., 26(11): pp. 1287-1293 (2006).

2. K. Kumari, N. Ranjan, and R. C. Sinha, "Solid waste management in Patna - analyses of ambient air and ground water pollution," Int. J. Environ. Technol. Manag., 14: 310-325, 2011.

3. S. Kumar, J. K. Bhattacharyya, A. N. Vaidya, T. Chakrabarti, S. Devotta, and A. B. Akolkar, "Assessment of the status of municipal solid waste management in metro cities, state capitals, class I cities, and class II towns in India: An insight," Waste Manag., 29(2): 883-895 (2009).

4. T. Narayana, "Municipal solid waste management in India: From waste disposal to recovery of resources?," Waste Manag., 29(3): 1163-1166, (2009).

5. N. Gupta, K. K. Yadav, and V. Kumar, "A review on current status of municipal solid waste management in India," J. Environ. Sci., 37 206-217 (2015).

6. S. Rathi, "Alternative approaches for better municipal solid waste management in Mumbai, India," Waste Manag., 26(10): 1192-1200, (2006).

7. M. Sharholy, K. Ahmad, G. Mahmood, and R. C. Trivedi, "Municipal solid waste management in Indian cities - A review," Waste Manag., 28(2): 459-467 (2008).
8. S. Gupta, K. Mohan, R. Prasad, S. Gupta, and A. Kansal, "Solid waste management in India: Options and opportunities," Resour. Conserv. Recycl., 24(2): 137-154 (1998).

9. P. K. Srivastava, K. Kulshreshtha, C. S. Mohanty, P. Pushpangadan, and A. Singh, "Stakeholder-based SWOT analysis for successful municipal solid waste management in Lucknow, India," Waste Manag., 25(5): 531-537, (2005).

10. K. Kumari, S. R. Singh, and R. C. Sinha, "Role of pollution control boards in municipal solid waste management Kanchan Kumari," Int. J. Environ. Technol. Manag., 17: 100-112 (2014).

11. CPCB, "Management of Municipal Solid Waste," Cent. Pollut. Control Board (Ministry Environemntal For., p. Government of India, (2000).

12. M. Sharholy, K. Ahmad, G. Mahmood and R. C. Trivedi, "Municipal solid waste management in Indian cities - A review". Waste Manag. 28: 459-467(2008). doi:10.1016/j. wasman.2007.02.008

13. S.M. Ali, A.P. Cotton, and K. Westlake,. "Down to Earth: Solid Waste Disposal for LowIncome Countries", WEDC, Loughborough University, UK (1999).

14. G. Tchobanoglous, $H$. Theisen, and R. Eliassan, "Solid WastesEngineering Principles and Management Issues", McGraw-Hill Book Company, New York, (1999). 